\title{
Biodegradation of Natural Rubber by Laccase and Manganese Peroxidase Enzyme of Bacillus subtilis
}

\author{
G. Nayanashree ${ }^{1}$ - B. Thippeswamy ${ }^{1,2}$
}

Received: 18 March 2015 / Accepted: 23 October 2015 / Published online: 2 November 2015

(C) Springer International Publishing Switzerland 2015

\begin{abstract}
The present study was carried out to isolate rubber degrading bacteria and to check the enzymes responsible for degradation, so that the isolates can be effectively used in rubber degradation. Different bacteria were isolated from soil samples and natural rubber samples collected from a rubber processing unit, and were screened for their ability to degrade natural rubber by plate assay. A biodegradation experiment was carried out in the laboratory to confirm degradation. Enzymes responsible for natural rubber degradation were characterized, crude enzyme was extracted by submerged fermentation process and its activity was determined. After extraction of crude enzyme, it was partially purified by dialysis process, and then, the enzyme activity and specific activity were determined. Then, the ability of these enzymes to degrade natural rubber discs were checked. The ability of natural rubber degrading microorganisms to degrade rubber products such as rubber gloves discs and rubber tire discs, was tested. Among the isolated bacterial species, Bacillus subtilis was predominant and showed growth on the natural rubber discs. The biodegradation experiment showed $48.6 \%$ weight loss. It was screened that laccase and manganese peroxidase enzymes are responsible for natural rubber degradation. When enzyme activity was determined, Bacillus subtilis, showed more manganese peroxidase activity compared to laccase activity. Laccase enzyme activity was $0.0138 \mathrm{IU}$ and manganese peroxidase activity was $0.0155 \mathrm{IU}$. The molecular weights of laccase enzyme $(64 \mathrm{kDa})$ and of manganese peroxidase enzyme $(68 \mathrm{kDa})$ were determined. Biodegradation of rubber by microorganisms was confirmed by Schiff's staining, SEM, FTIR and NMR studies.
\end{abstract}

Keywords Bacillus subtilis $\cdot$ Hevea brasiliensis $\cdot$ Vulcanization · Polyisoprene $\cdot$ Laccase · Manganese peroxidase

B. Thippeswamy

thippeswamyb272@yahoo.in

1 Department of P.G. Studies and Research in Microbiology, Bio-Science Complex, Jnanasahyadri, Kuvempu University, Shankaraghatta, Shivamogga (Dist.,), Karnataka 577 451, India

2 Visiting Scholar, Department of Plant Pathology, North Carolina State University, Raleigh, NC, USA 


\section{Introduction}

The term natural rubber or cahuchu (from Indian, $\mathrm{caa}=$ tears, $\mathrm{och} u=$ tree cahuchu $=$ weeping tree) refers to a coagulated or precipitated product obtained from latex of rubber plants (Hevea brasiliensis), which forms non-linked but partially vulcanizable polymer chains having molecular masses of about $10^{6} \mathrm{Da}$ with elastic properties. Latex serves as a clogging material during healing of wounds caused by mechanical injury of plants.

The natural rubber latex is sticky and viscous in nature and very sensitive to temperature, therefore, it cannot be directly used for the manufacturing of rubber products, unless subjected to vulcanization. Due to the special characters of the rubber it is extensively used worldwide. The global rubber consumption was estimated to be 12.5 million metric tons in 2013 of which $65 \%$ were used for tire production and the other $35 \%$ was used for the production of other rubber products (Tsuchii and Tokiwa 1999).

The average composition of the natural rubber latex is $25-30 \%$ polyisoprene, $1-1.8 \%$ proteins, 1-2 \% carbohydrates, $0.4-1.1 \%$ neutral lipids, $0.5-0.6 \%$ polar lipids, $0.4-0.6 \%$ inorganic components, $0.4 \%$ aminoacids and other 50-70\% water. Dry weight of the natural rubber latex contains more than $90 \%$ of cis-1, 4-polyisoprene and less than $10 \%$ of nonrubber constituents like proteins, carbohydrates, lipids etc. (Rose and Steinbüchel 2005).

After usage of these natural rubber products, their disposal is a major worldwide solid waste problem. The recommended priority order to reduce the volume of this kind of waste material is reduction of consumption, reuse of the product, recycling of the material, energy recovery and, as a final option, deposition of the product in the environment. Due to the chemical cross linking, it is not possible to simply melt and reshape rubber materials, as can be done with thermoplastics like polyethylene and polypropylene. In order to reuse rubber materials, special processes like grinding, pyrolysis and other thermal methods should be undertaken. During treatment by these methods, the material may become degraded to a certain extent and it will not gain its original characters. If it is burnt it will produce large amount of carbon-dioxide, chlorine gas which creates environmental problems and contributes to global warming. Natural rubber products, such as tires contain $1.5 \%$ by weight of hazardous substances. If dumped in landfills incidents of tire fires are common. Depending on the quantities of the material, the fire may go on for several days, creating a black smoke that may cover large parts of the township (Tsuchii et al. 1996).

Open burning of tire releases particulate matter and gases, such as sulphur compounds, hydrocarbons and oxides of carbon and nitrogen that are toxic to humans and to environment. The process also releases toxic pyrolitic oil into the environment. It is estimated that a single passenger car tire releases about 7.51 of pyrolitic oil during burning. Extinguishing the fire with water may enhance transportation of the oil, leading to soil and water contamination. Even storage of tires outdoors creates a conducive environment for breading of mosquitoes, which may cause malaria (Anonymous 2013).

There is also great danger to animals if rubber products, such as balloons, rubber sheets, bags, tubes and gloves, bands and others, are freely deposited or thrown in the natural environment. If rubber is consumed by animals, as it is a natural polymer, it will not be digested and may lead to death (Anonymous 2011).

One of the options of managing scrap rubber products is incineration; however, this is not a simple process. The incinerator must be properly designed to control air emissions and should be equipped with scrubbers to remove contaminants such as chlorine. Chlorine emissions generally would come from burning of waste rubber products and scrap that contain chloroprene 
polymers. The scrubbers generate an acidic product that may have to be neutralized prior to discharge. Almost all rubber compounds contain some type of fillers, either carbon blacks, clays, calcium carbonates or hydrated silica compounds. When these rubber compounds are burned, they generate ash which may contain heavy metals, like zinc. Thus, incineration is not a good solution for handling rubber waste (Tsuchii and Tokiwa 2001).

One of the ways of overcoming the environmental problems is by microbial transformation of rubber into useful products. There are many specific advantages of biotechnological processes compared to chemical and physical ones. Biotechnology does not produce any harmful or toxic chemicals and is normally not energy intensive. However, there are still some obstacles, most notably the sensitivity of microorganisms towards many chemical substances, including rubber additives, which are used to improve stability and function of tires over a wide temperature range.

Microbial degradation of rubber products has attracted much interest and many studies have been carried out on the degradation of both pure rubber elastomers and vulcanized rubber products by bacteria and actinomycetes (Breberg et al. 2002).

Thus, the present study concentrates on the isolation of natural rubber degrading bacteria and the identification of enzymes responsible for degradation.

\section{Materials and Methods}

For the isolation of bacteria, which are able to degrade natural rubber, soil sample was collected from a local landfill of Shivamogga district and brought to the laboratory. Natural rubber latex and natural rubber sheet samples were collected from rubber processing unit, and were brought to the laboratory and preserved in the refrigerator for further use.

\subsection{Isolation of Natural Rubber Degrading Bacteria}

For the isolation of natural rubber degrading bacteria, the soil burial method was followed. Natural rubber small discs were weighed and initial weight was recorded. Then, these discs were dumped in the soil and left for a total time period of six months; they, were regularly removed at time intervals of two, four and six months and weighed. For the isolation of natural rubber degrading bacteria soil sample and natural rubber samples were plated in nutrient agar and kept for incubation at room temperature at $37 \pm 2{ }^{\circ} \mathrm{C}$ for $24 \mathrm{~h}$ (Tsuchii et al. 1996).

The serial dilution method was followed for the isolation of bacteria from the soil sample brought from the local landfill area and latex contaminated soil brought from the rubber plantation. In this method, $1 \mathrm{~g}$ of soil was weighed and was added to the test tube containing $9 \mathrm{~mL}$ of sterile saline and mixed properly with the help of cyclomixer. From this test tube, $1 \mathrm{~mL}$ of suspension was pipetted out with the help of micropipette and transferred to another test tube containing $9 \mathrm{~mL}$ of sterile saline, and mixed well. Same procedure was repeated until $10^{-9}$ dilution was obtained, and from the last test tube $1 \mathrm{~mL}$ of suspension was discarded. Once the soil sample was serially diluted, the dilution was plated on the petriplates containing nutrient agar for the isolation of bacteria. Then, the plates were incubated at $37 \pm 2{ }^{\circ} \mathrm{C}$ for $24 \mathrm{~h}$ (Aneja 2004).

After isolation, bacteria were identified by using biochemical tests, Gram's staining, microscopic observation by binocular microscope using Bergy's manual (Peter et al. 1994). Biochemical tests used for bacterial identification were as follows: Malonate, Voges Proskauer's, Citrate, 
ONPG, Nitrate reduction, Catalase, Arginine, Sucrose, Mannitol, Glucose, Arabinose and Trehalose utilization. The colonies which were isolated were preserved at $4{ }^{\circ} \mathrm{C}$ in $2 \%$ agar slants.

\subsection{Plate Assay for the Screening of Bacteria Capable of Degrading Natural Rubber}

For the screening of natural rubber degrading bacteria, pure culture isolates of bacteria were directly inoculated on the sterilized, pre-weighed natural rubber discs and then kept for incubation for 2 months. Bacteria capable of degrading natural rubber utilized natural rubber as sole source of carbon and showed growth on the natural rubber discs. After a time interval of 2 months, natural rubber sample inoculated with organisms was washed thoroughly, dried at $50{ }^{\circ} \mathrm{C}$ in hot air oven for $24 \mathrm{~h}$ and final weight was recorded (Borel et al. 1981).

\subsection{Screening of Natural Rubber Degradation by Using Mineral Salt Medium (MSM)}

The natural rubber degrading ability of the bacteria was checked in laboratory conditions by growth experiment in mineral salt medium (MSM) (Pan et al. 2009), where natural rubber was used as sole carbon source. Previously isolated bacteria were inoculated to different conical flasks containing MSM and kept for incubation for 2 months on rotary shaker. Bacteria were incubated at $37 \pm 2{ }^{\circ} \mathrm{C}$, triplicates were maintained. After incubation period, natural rubber discs were removed and observed for bacterial growth. Then, natural rubber discs were washed, dried at $50{ }^{\circ} \mathrm{C}$ in hot air oven for $24 \mathrm{~h}$, and weight loss was checked (Tsuchii and Tokiwa 2001).

\subsection{Confirmation of Natural Rubber Degradation by Schiff's Staining}

Evidence for degradation and mineralization of cis-1, 4-polyisoprene rubber hydrocarbon chain was obtained by staining natural rubber discs containing actively growing colonies of microorganisms with Schiff's reagent. In a tightly stopper bottle, $10 \mathrm{~mL}$ of fuchsin reagent was added to a sample and kept for incubation for 10 to $30 \mathrm{~min}$ at room temperature. After this time, the excess amount of the reagent was discarded and $10 \mathrm{~mL}$ of the sulfite solution was added in order to suppress nonspecific reaction of blank sample (Berekaa et al. 2000).

\subsection{Confirmation of Natural Rubber Degradation by Scanning Electron Microscopy (SEM)}

Evidence for degradation and mineralization of cis-1,4-polyisoprene natural rubber hydrocarbon chain was obtained by observing the natural rubber discs buried in the soil and present in the MSM under field emission-scanning electron microscopy (FEI-SIRION, Eindhoven, Netherland) (Lions et al. 2000).

\subsection{Confirmation of Natural Rubber Degradation by Fourier Transform Infrared Spectroscopy (FTIR)}

Chemical changes that arose directly on the natural rubber surface as result of the degradation process were determined using FTIR spectroscopy. NICOLET 380 FTIR spectrophotometer 
from Thermo Fisher Scientific, France was used which gives transmittance spectra in IR range 4000 to $400 \mathrm{~nm}$ (Roy et al. 2005).

\subsection{Confirmation of Natural Rubber Degradation by Nuclear Magnetic Resonance Spectroscopy (NMR)}

Structural changes that arose directly on the natural rubber surface as result of the degradation process were determined using NMR spectroscopy. $400 \mathrm{MHz}$ Supercon from Bruker, West Germany, with multi-nuclear probe, which is commonly used to study $\mathrm{H} 1 \mathrm{NMR}$ and ${ }^{13} \mathrm{C}$ NMR, was used to study structural changes of rubber sample treated with microorganisms (Shah et al. 2008).

\subsection{Screening and Characterization of Laccase and Manganese Peroxidase Enzyme}

Screening for laccase enzyme produced by Bacillus subtilis was done on plates containing the following composition $(\mathrm{g} / \mathrm{L})$ : 3.0 peptone, 10.0 glucose, $0.6 \mathrm{KH}_{2} \mathrm{PO}_{4}, 0.001 \mathrm{ZnSO}_{4}, 0.4$ $\mathrm{K}_{2} \mathrm{HPO}_{4}, 0.0005 \mathrm{FeSO}_{4}, 0.05 \mathrm{MnSO}_{4}, 0.5 \mathrm{MgSO}_{4}, 20.0$ Agar (pH-6) supplemented with $0.02 \%$ guaiacol. Bacillus subtilis was inoculated into this plate and the plate was incubated at $30{ }^{\circ} \mathrm{C}$ for 7 days. Laccase activity was visualized on plates containing $0.02 \%$ guaiacol, since laccase catalyzes the oxidative polymerization of guaiacol to form reddish brown zones in the medium (Viswanath et al. 2008).

For the screening of manganese peroxidase enzyme producing organisms $\mathrm{H}_{2} \mathrm{O}_{2}$ was added to the laccase screening media.

\subsection{Mass Production of Enzyme by Submerged Fermentation}

A pure culture of Bacillus subtilis was inoculated to submerged state fermentation medium for the production of extracellular enzymes by using MSM media and was maintained at the incubation temperature of $37 \pm 2{ }^{\circ} \mathrm{C}$ for 2 months (Shraddha et al. 2011).

\subsection{Determination of Laccase and Manganese Peroxidase Enzyme Activity by Using a Spectrophotometer}

Guaiacol $(2 \mathrm{mM})$ in sodium acetate buffer $(10 \mathrm{mM}, \mathrm{pH} 5.0)$ was used as substrate. The reaction mixture contained $3 \mathrm{~mL} 10 \mathrm{mM}$ acetate buffer of $\mathrm{pH} 5,1 \mathrm{~mL}$ guaiacol and $1 \mathrm{~mL}$ enzyme source, and enzyme blank contained $1 \mathrm{~mL}$ of distilled water instead of enzyme source. The mixture was incubated at $30{ }^{\circ} \mathrm{C}$ for $15 \mathrm{~min}$ and absorbance was read at $450 \mathrm{~nm}$ blank using UV spectrophotometer (Papinutti and Martinez 2006). Manganese peroxidase enzyme activity was calculated by following the laccase enzyme activity determination procedure, but for the reaction mixture $1 \mathrm{~mL}$ of $\mathrm{H}_{2} \mathrm{O}_{2}$ was added and incubated.

\subsection{Protein Estimation}

Protein concentration was estimated to determine specific activity of enzyme. The protein concentration was determined by the Lowry's method (Lowry et al. 1951), using Bovine Serum Albumin (BSA) as a standard, absorbance was read at $660 \mathrm{~nm}$ using JENWAY- 6305 UV-VIS Spectrophotometer. 
Table 1 Biochemical tests for identification of bacteria

\begin{tabular}{lll}
\hline Sl. No. & Name of the biochemical test & Bacillus subtilis \\
\hline 1. & Malonate (M) & - \\
2. & Voges & + \\
& Proskauer's (V) & + \\
3. & Citrate (C) & + \\
4. & ONPG (O) & + \\
5. & Nitrate Reduction (N) & + \\
6. & Catalase (Ca) & - \\
7. & Arginine (A) & + \\
8. & Sucrose (S) & + \\
9. & Mannitol (M) & + \\
10. & Glucose (G) & + \\
11. & Arabinose (Ar) & + \\
12. & Trehalose (T) & \\
\hline
\end{tabular}

\subsection{Partial Purification of Enzyme}

The obtained culture filtrates were centrifuged and the supernatant was precipitated by $70 \%$ saturation using ammonium sulphate, and then, dialyzed against $50 \mathrm{mM}$ phosphate buffer ( $\mathrm{pH} \mathrm{7.0)} \mathrm{for} 24 \mathrm{~h}$. SDS-PAGE electrophoresis was carried out for the partially purified enzymes and the molecular weight was determined by using standard marker (Shraddha et al. 2011).

\section{Results}

\subsection{Isolation of Natural Rubber Degrading Bacteria}

Rubber samples and the soil sample of 2, 4 and 6 months were plated on the nutrient agar, various bacteria, like Bacillus sp. and Pseudomonas sp., were isolated and recorded. Among them, one bacterial species was pre-dominant and commonly isolated and identified, Bacillus subtilis (Table 1, Fig. 1). Thus, it was screened to test natural rubber degrading ability. Weight loss was also observed in all rubber samples, which were removed at different time interval (Table 2).

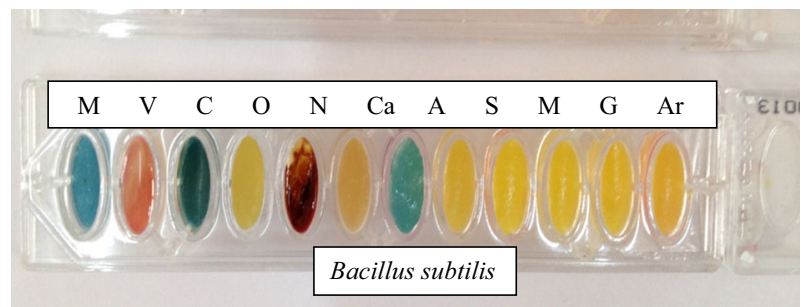

Fig. 1 Biochemical tests performed for identification of bacteria 
Table 2 Weight loss of natural rubber by soil burial method

\begin{tabular}{llllll}
\hline S1.No. & Number of months & Initial weight $(\mathrm{g})$ & Final Weight $(\mathrm{g})$ & Weight loss $(\mathrm{g})$ & Weight loss In (\%) \\
\hline 1. & 2 & 3 & 2.84 & $0.16 \pm 0.01$ & 5.3 \\
2. & 4 & 3 & 2.63 & $0.37 \pm 0.04$ & 12.3 \\
3. & 6 & 3 & 2.12 & $0.88 \pm 0.01$ & 29.3 \\
\hline
\end{tabular}

\subsection{Plate Assay for the Screening of Microorganisms Capable of Degrading Natural Rubber}

In Bacillus subtilis inoculated natural rubber discs, the initial weight of the rubber disc was $10 \mathrm{~g}$ and final weight was $7.54 \mathrm{~g}$. There was a decrease of $2.46 \pm 0.06 \mathrm{~g}(n=3)$ weight and the percentage of weight loss was $24.6 \%$.

\subsection{Screening of Natural Rubber Degradation by Using Mineral Salt Medium (MSM)}

Growth experiment was conducted by using mineral salt medium. Weight loss and growth of bacteria were observed on the natural rubber discs. Initial weight of Bacillus subtilis inoculated sample was $3 \mathrm{~g}$ and final weight was $1.54 \mathrm{~g}$. There was a weight loss of $1.46 \pm 0.01 \mathrm{~g}(n=3)$ or $48.6 \%$ weight loss.

\subsection{Confirmation of Natural Rubber Degradation by Staining with Schiff's Reagent}

Natural rubber discs inoculated with Bacillus subtilis turned to purple colour, while there was no colour formation in the untreated control. Formation of purple colour in the treated sample was due to the presence of aldehyde and ketone groups, which were produced as a result of degradation of cis-1,4-polyisoprene units of natural rubber (Fig. 2).

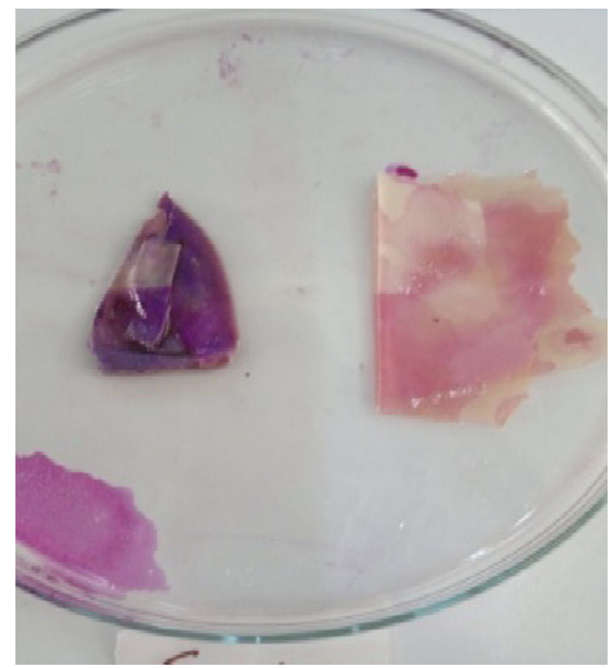

Fig. 2 Confirmation of Natural rubber degradation by staining with Schiff's reagent 


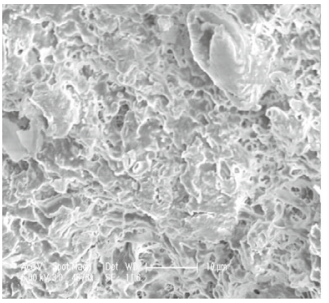

Sample buried in soil

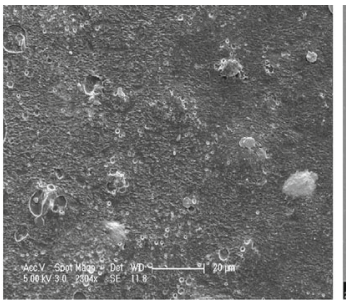

Bacillus subtilis treated

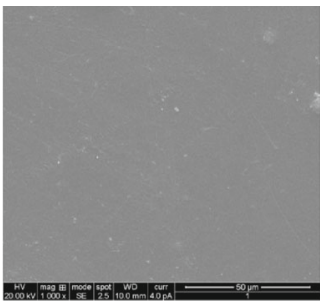

Control

Fig. 3 SEM images of natural rubber showing degradation

\subsection{Confirmation of Natural Rubber Degradation by Scanning Electron Microscopy (SEM)}

Natural rubber discs were observed under SEM. Bio-film formation, complete disintegration and formation of cavities on the natural rubber discs were observed (Fig. 3).

\subsection{Confirmation of Natural Rubber Degradation by Fourier Transform Infrared Spectroscopy (FTIR)}

Natural rubber discs, treated by bacteria were subjected to FTIR studies. Peaks were observed at the wave length between $2725.89 \mathrm{~cm}^{-1}$ and $1662.34 \mathrm{~cm}^{-1}$ having $\mathrm{H}-\mathrm{C}=\mathrm{O}: \mathrm{C}-\mathrm{H}$ stretch and $\mathrm{C}=\mathrm{O}$ stretch which indicates the presence of aldehyde and ketone released as a result of natural rubber degradation in the treated sample. Presence of these aldehyde and ketone groups confirms natural rubber degradation. Peaks showing the presence of aldehyde and ketone were absent in control (Fig. 4).

\subsection{Confirmation of Natural Rubber Degradation by Nuclear Magnetic Resonance Spectroscopy (NMR)}

Structural changes that arose directly on the natural rubber surface as a result of the degradation process were determined using NMR spectroscopy. When rubber discs treated by microorganisms were tested by NMR, peaks showing the change in the structure of the rubber were observed. Presence of aromatic protons, NH protons, NH4 protons and aliphatic chains shows the degradation of natural rubber by microorganisms, which was absent in the control (Fig. 5).

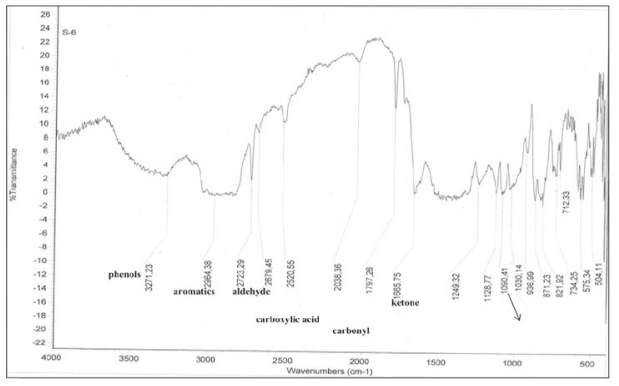

Bacillus subtilis treated sample [2A]

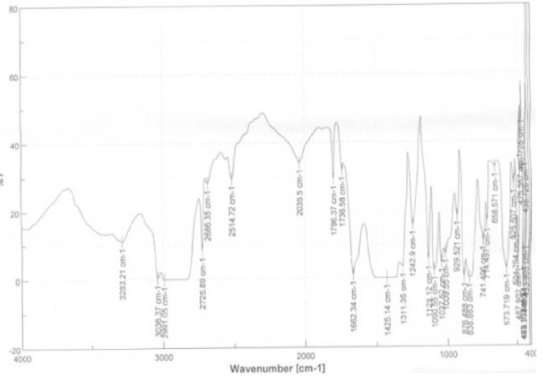

Control[2B]

Fig. 4 Confirmation of natural rubber degradation by FTIR 


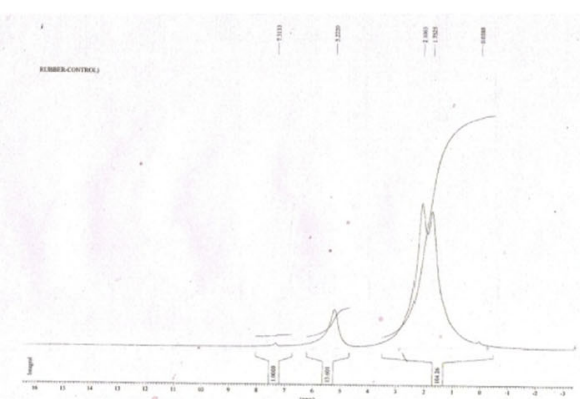

Control

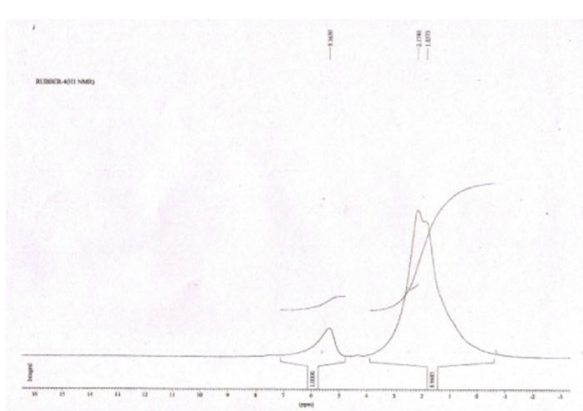

Bacillus subtilis treated

Fig. 5 Confirmation of natural rubber degradation by NMR

\subsection{Screening and Characterization of Laccase and Manganese Peroxidase Enzyme}

Bacillus subtilis was inoculated on the laccase and manganese peroxidase medium. There was a formation of reddish brown colour around the colonies, as laccase and manganese peroxidase catalyzes the oxidative polymerization of guaiacol to form a reddish brown zone. Bacillus subtilis which showed a positive result on rubber degradation showed a positive result on laccase and manganese peroxidase enzyme screening (Fig. 6).

\subsection{Spectrophotometrical Analysis of Laccase and Manganese Peroxidase Enzyme Activity}

Bacillus subtilis, showed more manganese peroxidase activity compared to laccase activity. Both laccase and manganese peroxidase enzyme activity was maximum in 7 th week. Laccase enzyme activity in 7 th week was 0.0138 IU and manganese peroxidase activity in 7 th week was $0.0155 \mathrm{IU}$ (Table 3, Fig. 7).

\subsection{Protein Estimation}

Specific activity of laccase enzyme in Bacillus subtilis was $0.217 \pm 0.002 \mu \mathrm{mol} / \mathrm{mL} / \mathrm{min} / \mathrm{mg}$ and specific activity of manganese peroxidase enzyme in Bacillus subtilis was $0.251 \pm 0.002 \mu \mathrm{mol} / \mathrm{mL} / \mathrm{min} / \mathrm{mg}$.

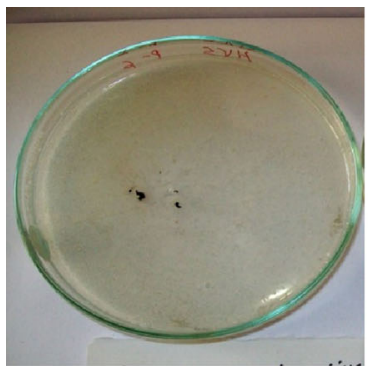

Control

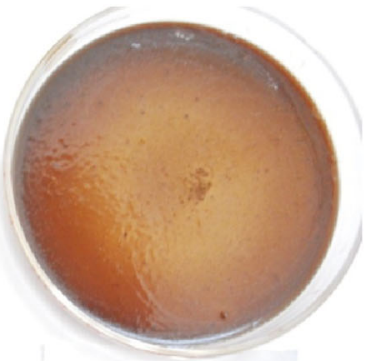

Laccase enzyme

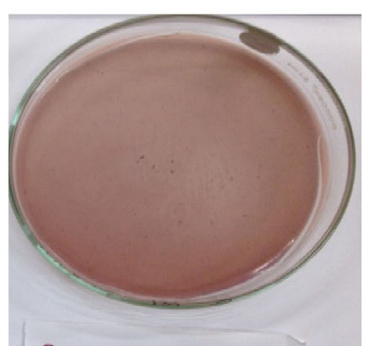

Manganese peroxidase enzyme

Fig. 6 Bacteria showing positive result for Laccase and Manganese peroxidase enzyme 
Table 3 Laccase and Manganese peroxidase enzyme activity in IU

\begin{tabular}{llllllllll}
\hline Bacillus subtilis & 1st week & 2nd week & 3rd week & 4th week & 5th week & 6th week & 7th week & 8th week \\
\hline Laccase & 0.0023 & 0.0037 & 0.0054 & 0.0074 & 0.0098 & 0.0119 & 0.0138 & 0.0116 \\
Manganese peroxidase & 0.0026 & 0.0044 & 0.0065 & 0.0086 & 0.0107 & 0.0129 & 0.0155 & 0.0134 \\
\hline
\end{tabular}

\subsection{Partial Purification of Enzyme}

By performing SDS-PAGE, the molecular weight of laccase and manganese peroxidase enzyme of Bacillus subtilis was determined. The molecular weight of laccase enzyme was $64 \mathrm{kDa}$ and molecular weight of manganese peroxidase enzyme was $68 \mathrm{kDa}$ (Fig. 8).

\section{Discussion}

The present study was carried out to isolate natural rubber degrading bacteria. It was observed that Bacillus subtilis is capable of degrading natural rubber. Degradation of natural rubber was studied by carrying out growth experiment in MSM where $48.6 \%$ weight loss was observed and degradation was confirmed by staining, SEM, FTIR and NMR studies. Further, enzymes responsible for degradation were identified, which were laccase and manganese peroxidase. Enzyme activity was determined spectrometrically. Both laccase and manganese peroxidase enzyme activity was maximum in 7 th week, with respective activities 0.0138 IU and 0.0155 IU.

Further, by performing SDS-PAGE, the molecular weights of laccase and manganese peroxidase enzymes of Bacillus subtilis were determined. The molecular weights of laccase and manganese peroxidase enzymes were $64 \mathrm{kDa}$ and $68 \mathrm{kDa}$, respectively.

Similar attempts to degrade rubber by using microorganisms have been made in the past by several other scientists.

Roy et al. (2005) studied natural rubber (NR) biodegradation through solid-state fermentation (SSF). Submerged fermentation (SMF) was carried out for both bacterial as well as fungal species. There were changes in the organic carbon content and the average molecular weight of the treated rubber samples, indicating utilization of rubber hydrocarbon and its degradation.

Berekaa et al. (2000) conducted similar work and tested the biodegrading ability of different bacteria belonging to the genera Gordonia (strains $\mathrm{Kb} 2, \mathrm{Kd} 2$ and $\mathrm{VH} 2$ ), Mycobacterium,

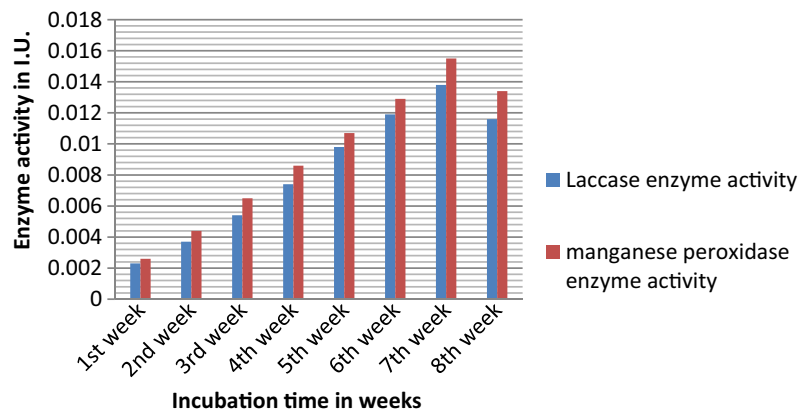

Fig. 7 Laccase and manganese peroxidase enzyme activity in IU 


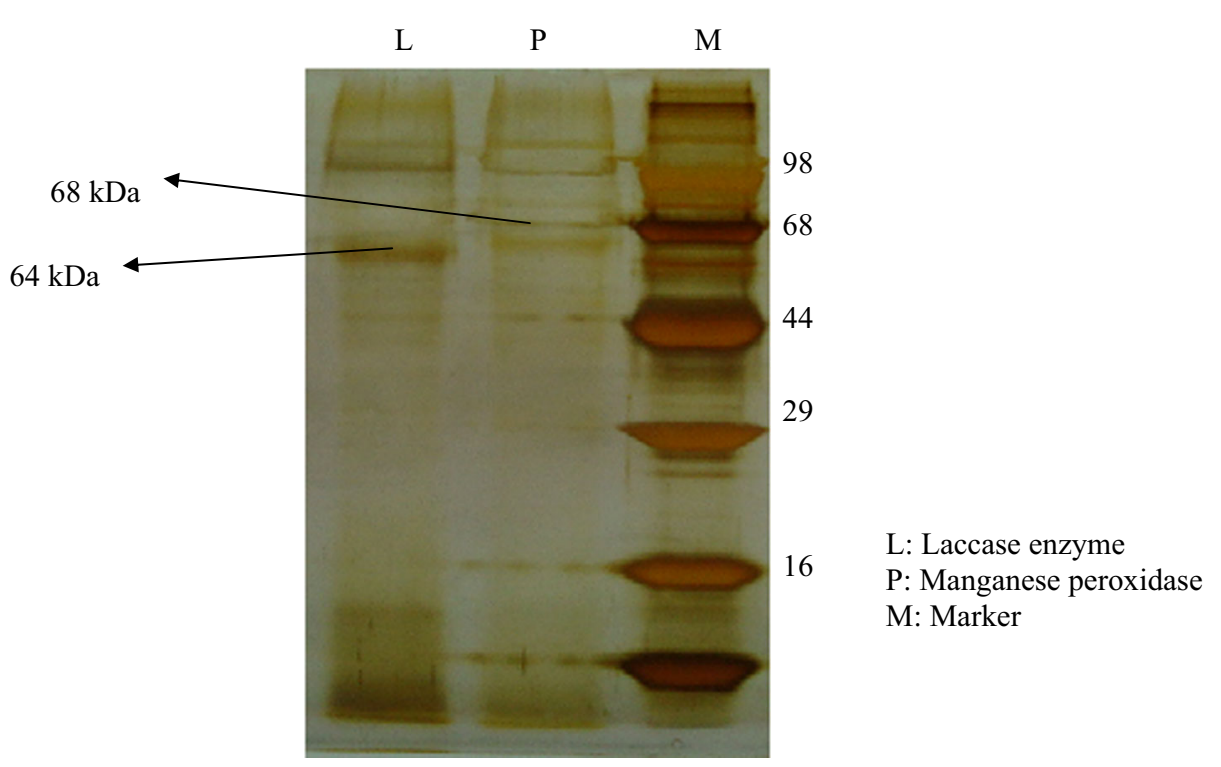

Fig. 8 Molecular weight of laccase and manganese peroxidase enzyme of Bacillus subtilis

Micromonospora and Pseudomonas. All strains were able to use natural rubber (NR) as well as NR latex gloves as sole carbon source.

A similar study was carried out by Tsuchii and Tokiwa (1999). They showed that $47 \%$ of a tire tread strip with a natural rubber content of 100 parts per hundred of rubber was completely mineralized by a mutant strain, Rc, of the rubber-degrading organism, Nocardia sp.

\section{Conclusions}

One of the alternative ways to manage rubber solid waste is to subject rubber products to biodegradation. In the present study, rubber discs burried in the soil were removed at regular time period and then tested to isolate rubber degrading organisms. Among the isolated organisms, Bacillus subtilis was found to effectively degrade the rubber samples. Thus, it is possible to use Bacillus subtilis to effectively degrade natural rubber. Laccase and manganese peroxidase enzyme were partially purified and their enzyme activity and molecular weights were determined.

The present work concludes that the isolated strain can be successfully used for the biodegradation of natural rubber and its products, but as it is a biological process it requires time.

Acknowledgments We thank Kuvempu University, Shankaraghatta-577 451, Shivamogga (Dist.,), Karnataka, India, for the financial support to carry out the extensive research work.

\section{References}

Aneja KR (2004) Experiments on Microbiology, Plant Pathology and Biotechnology. 4th ed. New Age International Pvt. Ltd. New Delhi. 1-607

Anonymous (2011) Malaysian rubber board, 47000. Sungei Buloh, Selangor 
Anonymous (2013) Complete information on area and production of rubber in India, Essay on Science Laboratory

Berekaa MM, Lions A, Reichelt R, Keller U, Steinbuchel A (2000) Effect of pretreatment of rubber material on its biodegradability by various rubber degrading bacteria. FEMS Microbiol Lett 184:199-206

Borel M, Kergomard A, Renard F (1981) Degradation of natural rubber by bacteria imperfecti. Agric Biol Chem 46:877-881

Breberg K, Andersons EB, Landfors E, Holst O (2002) Microbial detoxification of waste rubber material by wood rotting fungi. Bioresour Technol 83:221-224

Lions A, Rudolf Reichelt R, Keller U, Steinbuchel A (2000) A Gram negative bacterium identified as Pseudomonas aeruginosa, AL98, is a potent degrader of natural rubber and synthetic cis-1,4-polyisoprene. FEMS Microbiol Lett 182:155-161

Lowry OH, Rosebrough NJ, Farr AL, Randall RJ (1951) Protein measurement with the folin phenol reagent. J Gen Microbiol 31:3017-3027

Pan L, Gung GJ, Yin B, Cheng PS (2009) Contribution to deterioration of polymeric materials by slow growing bacteria nocardia corynebacterioides. Int Biodeterior Biodegrad 63:24-29

Papinutti L, Martinez JM (2006) Production and characterization of laccase and manganese peroxidase from the ligninolytic fungus fomes sclerodermeus. J Technol Biotechnol 81:1064-1070

Peter HA, James T, Stanley T (1994) Bergey's Manual of Determinative Bacteriology. 9th edition: 1-754

Rose K, Steinbüchel A (2005) Biodegradation of natural rubber and related compounds: recent insights into a hardly understood catabolic capability of microorganisms. Appl Environ Microbiol 71:2803-2812

Roy VR, Das M, Banerjee R, Bhowmick A (2005) Comparative studies on rubber biodegradation through solid state and submerged fermentation. Process Biochem 42:181-186

Shah AA, Hasan F, Hameed A, Ahmed S (2008) Biological degradation of plastics: a comprehensive review. Biotechnol Adv 26(246):265

Shraddha SR, Sehgal S, Kamtania M, Kumar A (2011) Laccase microbial source production, purification, potential biotechnological application. Enzym Res 2011:1-11

Tsuchii A, Tokiwa Y (1999) Colonization and disintegration of tire rubber by a colonial mutant of nocardia. J Biosci Bioeng 87:542-544

Tsuchii A, Tokiwa Y (2001) Microbial degradation of tire rubber particles. Biotechnol Lett 23:963-969

Tsuchii A, Takeda K, Suzuki T, Tokiwa Y (1996) Colonization and degradation of rubber pieces by nocardia species. Biodegrad J 7:41-48

Viswanath B, Chandra MS, Pallavi H, Reddy R (2008) Screening and assessment of laccase producing bacteria isolated from different environmental samples. Afr J Biotechnol 7:1129-1133 